\title{
Impact of Coronavirus Lockdown among the Seventh - day Adventist Community Members in Masvingo Urban, Zimbabwe
}

\author{
Rodgers Manungo, PhD* and Tinashe Rukuni, PhD \\ Great Zimbabwe University \\ "Corresponding Mail: rmanungo@gzu.ac.zw
}

\begin{abstract}
This study sought to establish the financial, spiritual and social impact of the Coronavirus lockdown among the Seventh-day Adventist community members in Masvingo Urban, Zimbabwe. The study focused on how the households, the informally employed parents and students perceived their financial, spiritual and social status during the lockdown, especially pertaining to the positives and negatives that might have emanated from the period. The study employed the participant oriented interpretive phenomenological approach, which allowed the respondents to share their lived experiences during the period. The four SDA districts in Masvingo have about 4000 members who were all given a chance to participate in the study. From these, 35 members who comprised 20 males and 15 females of between 16 and above 55 years, from the parent and student categories returned the questionnaire within the stipulated two week period directly to the researchers and via their pastors. Collected data was coded according to the financial, spiritual, and social experiences, which were further divided into subthemes. Key findings revealed that members of the church, who were involved in the formal and informal sectors of the economy, were financially affected during the lockdown. Some members were spiritually affected, due to boredom; hence some broke the Sabbath regulations. Some found the alternative radio, television and online Christian programs spiritually uplifting, though. Socially, members were affected by the inter-provincial, inter-district and national border restrictions imposed at the time. Evidently, some members took the time to bond with their immediate family. The study recommends that there be plans in place to address the financial and physical needs of the members on the part of the government and the private sector, including the church during lockdowns; such plans should also include effective distribution methods of these resources to the households. Further, the church needs to introduce more radio and television programs.
\end{abstract}

Keywords: Coronavirus, Pandemic, Lockdown, Financial, Spiritual, Social, Seventh-day Adventist

\section{Introduction}

The novel Coronavirus, also known as 2019-nCoV or COVID-19, and pneumonia of unknown origin, broke out in Wuhan City, China, in late 2019 before it spread to all the corners of the universe with terrible consequences. The period between February and November 2020 witnessed a number of confirmed cases as well as the death toll spiking and spiraling out of control, especially in Europe and North America, while South Africa had the highest toll of confirmed cases in Africa. As of November 2020, the virus had directly and indirectly affected millions with the infected, death and recovery numbers at over 58.2 million, over 1.3 million and over 40 million, respectively (World Health Organization, 2020). The physical impact of the pandemic ran parallel to the fear and panic experienced across the globe, and this stirred unforgettable experiences. Gostin (2020) postulates that the spread of infectious diseases knows no boundaries and has been part of globalization for a while, cutting across borders, regions and continents. Coming to the immediate challenge of the Coronavirus, Malik and Naeem (2020) say that the pandemic might have mostly affected women, though with little research on the magnitude of such an effect.

Additionally, there was a general observation that gender-based violence might have gone up, due to the social and economic pressures that came as a result of the lockdown (Nkwe, 2020). The pandemic disrupted people's way of life, individually and 
collectively. Due to the pressure of the pandemic, the situation put individuals, families, communities and countries under serious health and economic stresses, increasing the possibilities of family disintegration, violence, corruption, exploitation and neglect. Overall, the Coronavirus caused political, social and economic constraints in developed, developing and underdeveloped countries, though with different consequences.

In the attempt to curb the spread of the Coronavirus, self-isolation witnessed quarantine measures, including the closure of organizations and institutions. Those affected included churches and companies, most of them having to improvise ways of working from homes. The SDA church in Zimbabwe introduced and improvised ways of collecting tithes and offerings as well as having prayer and preaching services via alternative media, such as the television, WhatsApp, Facebook, Instagram, amongst others. The overall economic and social impact of the virus, and the effects of these new ways of delivery by the different church denominations remain largely unknown in Zimbabwe, including in the Masvingo SDA church. Soon after the call for social distancing, use of masks and isolation by the World Health Organization, the government called for businesses to shut down, including the churches; the measures were gradually relaxed though. As a result of the first directive, the SDA church in Masvingo also closed its doors on its members. Some members met in small numbers in houses, while others resorted to watching church programs via different media outlets. It is with this in mind that this study sought to find out how such isolation due to the Coronavirus affected the SDA community in Masvingo. This study was guided by the following research questions:

1. How were the SDA members in Masvingo affected financially during the Coronavirus lockdown?

2. How did the lockdown affect the SDA members spiritually?

3. How did the lockdown impact the SDA church members socially?

\section{Political and Socio-economic Impact of the Coronavirus}

Whenever there is a pandemic, there is panic amongst the citizens and institutions. One of the consequences running parallel to the recent Coronavirus is apprehension around terrorism.
According to Basit (2020), since the outbreak of the virus, belligerent groups have taken to social media, with heightened messages that promote hatred, end-time narratives and apocalyptic conspiracies. The pandemic appears to have created a niche for such since national governments are pre-occupied with on-going health issues to pay much attention to the new and extended war-paths such groups have taken. Given that the majority of the recent century conflicts are complex and tend to overlap, Basit further postulates that the so-called "terrorist" groups, such as the Taliban, IS and Al-Qaeda have taken advantage and sought to revenge on their "enemies" by rendering their ideological worldview and narratives from their standpoints. That means such ultra-radical groups have heightened their rhetoric as they take advantage of the on-going situation caused by the Coronavirus. By chance, as a result of the pandemic, the likes of Canada, Spain, France and the UK have joined the US in drastically reducing their anti-IS troop-presence in Iraq, while further training of the Iraq troops was put on hold (Nicholls, 2020; Ackerman, 2020). Consequently, when the Coronavirus hit Wuhan, it was convenient for IS to assert that this was a result of God's wrath against communist China.

The Taliban had the guts and courage to call the Western World to change camps by conforming to Islam (Joscelyn, 2020), and the group went on a public relations spree that included calls for the Afghan government to release prisoners, who might be infected by the pandemic (Basit, 2020). Besides, it also even invited international organizations such as the International Committee of Red Cross to visit territories under its control in addition to calling for a truce with the Afghan government (Gannon, 2020). While peace practitioners might view this as an opportunity for peacebuilding, which has been presented by the pandemic, the fractured relations between the groups are at their lowest ebb, hence the belligerent groups might never be taken seriously. According to Basit (2020), other religious overtones have witnessed far-right and neo-Nazi groups promoting anti-Semitic and xenophobic language via media outlets, such as Twitter, Gab, Facebook, YouTube and Instagram, by accusing the Jews of manufacturing the pandemic. The balance has shown that the Coronavirus period saw an upsurge in a hate language being perpetrated by the radical belligerent groups, especially against the Western world, whose attention is currently drawn towards curbing the effects of the pandemic. While 
the elements in radical groups might have been taking advantage of the situation, the Western world, especially the US, was also accused of using the disease to their advantage.

Real or imagined, vaccination itself has never been short of apprehension amongst a certain group, with conspiracy theories usually raising an ugly head. The US, via the CIA, has usually been accused of taking desperation for vaccines to settle scores. Another case, which turned almost comical, and also served as a reminder of the Cold War tensions, was the notable competition for vaccines between the US and Russia. Once Pfizer hinted that they have developed a 90 percent effective vaccine, the Russian President, Putin, responded by arguing that the Russian vaccine, Sputnik V, was 92 percent effective (Magnay, 2020). Gostin (2014) postulates that war-torn communities in the likes of Syria, Nigeria and Afghanistan have never been short of CIA's ploys to get rid of perceived enemies through contaminated vaccines. By mid-2020, there were populations in several countries, which showed tiredness of the lockdowns and merely wearing masks, as well as how the central governments handled the Coronavirus; this also gave a chance to others to settle unfinished political issues, hence demonstrations in the likes of Israel, Belarus and Thailand, while the Lebanon explosion and Black Lives Matter movement in the USA also led to massive demonstrations at the height of the scourge.

Given the assertion that when North America sneezes, the world catches a cold, there has always been a lot of global attention on the nation. At the height of the Coronavirus, the US went through its national elections pitting Donald Trump (Republican Party) and Joseph Biden (Democratic Party). While the elections were won by Biden, it was argued that one of the reasons for Trump's loss was how he handled the pandemic. By November 2020, his administration had not settled the stimulus for the business, in addition to the former President asserting that the "Corona, Corona, Corona, Corona everywhere..." rhetoric was only meant to intimidate and frighten the Americans (Reston, 2020). Despite being infected by the virus at some point, Trump and his supporters continued to be seen at political rallies without face masks. If Trump was in denial about the impact of the Coronavirus, then he found a partner, the late Tanzanian President, John Magufuli in whose speech during a church service, he likened the pandemic to the Devil and needed divine intervention to be curbed (Iroulo \& Boateng, 2020). Consequently, he argued that churches and mosques would remain open, because that is where true salvation was found. The influence of model political and religious leaders was discovered to pose a great threat to the implementation of measures to curb the spread of the Coronavirus pandemic. The projected economic impact of the Coronavirus appeared unprecedented in the first half of 2020. One of the sectors that showed strain was the petroleum industry, which was hit by a decline in prices. Between January and February, the price of Brent oil had dropped from $\$ 68.90$ to $\$ 50.5$ a barrel at international level (Arezki \& Nguyen, 2020). Similarly, the virus also affected the international price of crude oil. Arezki et al (Ibid) add that it tumbled by $\$ 20$ a barrel during the same months. Apparently, there was a drop in oil demand, especially by one of the biggest consumers, China, which closed production facilities to curb the spread of the virus.

One of the strategies to curb the virus was a lockdown, hence one of the most affected industries was tourism and travel. By mid-2020, the majority of the world's economies had shut this industry. So dire was the situation created by the pandemic that Saudi Arabia suspended the annual pilgrimages to the holy sites for the Muslims (Arezki et al, 2020). This was not good for business and a lot of countries felt a pinch. Automatically, lack of travel impacted on other industries that were dependent on tourism. The economic impact of the Coronavirus varied across the different industries, and each country addressed challenges caused by the pandemic differently; notably, the developed countries provided stimuli funds to cushion industry. A survey in the United States between March and April 2020 showed that 43 percent of the small businesses had temporarily closed largely due to the pandemic (Bartik, Bertrandb, Cullenc, Glaeserd, Lucac \& Stanton, 2020). According to findings, most businesses closed due to reduced demand, as well as health concerns, and less due to the disruptions in the supply chain. Critically, and as noted elsewhere, employment was reduced by between 39 and 47 percent in different states (Bartik et al, 2020). Other small industries that have been affected include arts and entertainment, food services, hospitality, among others, which were reduced by 50 percent by April 2020. As discovered elsewhere, many African regions, including the horn of the continent faced the unknown future, since 
extremism of groups, such as Al Shabaab, could use the pandemic as a launch-pad to recruit and increase their standing in Somalia, as well as across the region (AU \& UNDP, 2020). The pandemic was also likely to increase political and socio-economic instability on the continent.

\section{Gender and Coronavirus}

The usual suspect of suffering during conflicts and pandemics are women and children. While in certain cases they are perpetrators, the two sectors of society are usually vulnerable to abuse of one sort or the other, some of the victims and survivors being raped, maimed or killed. While women have been known to be largely affected during the direct violence, growing evidence of the same during the Coronavirus pandemic was notable. While the Coronavirus seriously affected the formal sector, leading to a lot of workers losing employment and salaries, the informal sector might have been the worst hit. According to Malik et al (2020), the harsh realities of COVID-19 showed that 2 billion workers in the informal sector were affected, especially females. This is also based on the assertion of the United Nations that 65 percent of women from this sector faced a bleak future due to economic uncertainties (Haldevang, 2020). According to Malik et al (2020), most emerging and developing nations' informal sectors are dominated by female workers, with most of them showing signs of strain, being deprived of social protection, as well as falling prey to the jaws of poverty, due to the pandemic. Unfortunately, signs also pointed to this group not recovering at the end of the pandemic.

Out of the findings of Malik et al (2020) in Pakistan, the position of female workers in the informal sector was exacerbated by the fact that they got paid minimum wages. This group, which faces multi-dimensional uncertainties, due to lack of social protection, includes domestic workers and those in the home-based small and medium businesses, among others. While the lockdown impacted the informal sector, the formal sector in the developed and developing economies were not spared either. Alam and Kurtenabch (2020) found out that sectors, such as construction, apparel and other manufacturing ones were hard-hit in the likes of Myanmar, Vietnam and Cambodia, especially amongst the female workers. Though the male workers might have been affected to some extent, the situation of the female workers was observed to be dire, since they also had to deal with the burdens of the domestic environment (Malik et al, 2020).
The health sector is also generally dominated by female health workers. For instance, Boniol, Mclssac, Xu, Wuliji, Diallo and Campbell (2019) reveal that the world's workforce in the health sector is fronted by around 70 percent females, and this is the group that dominates those on the frontline against the pandemic. In China, the number of female nurses and paramedics that fought the Coronavirus from the front was as high as 90 percent (Wenham, Smith \& Morgan, 2020). For now, the effects of the virus on the different genders remain unclear, but the pandemic might have ripple effects that include mental illnesses and trauma, which are likely to mostly affect female workers, compared to their male counterparts.

Effects of the Coronavirus on women in Africa may need further studies, but results found elsewhere are synonymous with the finding and projections of the UNDP and the AU in the horn of Africa. In addition to the on-going chaos in the likes of Somalia, it was asserted that the pandemic particularly affected the youth and women, pushing some from these groups into extremism, crime and violence (AU \& UNDP, 2020). Also, projections of the effects of the Coronavirus asserted that the farreaching economic, health and closure of schools in East, Central and Southern Africa, would mostly affect women and girls. The likelihood of this was more pronounced, since women in the aforementioned areas contribute 70 percent of the frontline healthcare workers and dominate the informal sector (AU \& UNDP, 2020). It is also critical to note that the $A U$ and the UNDP (Ibid) observed the likelihood of lack of access to gender-based support and reproductive and sexual health services, hence an increase in maternal and mortality rates.

\section{The impact of Coronavirus in Africa}

Pertaining to the Coronavirus, Madagascar felt it was being ignored after 'finding' a vaccine for the Coronavirus. Given that the vaccination program was being led by the national government, the Madagascan argument gained traction, especially on the African continent (Oduor, 2020). Botswana confirmed its first Coronavirus case in March 2020, though the country secured its national borders after neighboring Zimbabwe recorded its first death (Dube, 2020). Since then, the country introduced and reintroduced measures that are meant to curb the spread of the pandemic, with Kahla (2020) postulating that the pandemic may continue for two years. Eswatini had its first Coronavirus case 
confirmed in March 2020 through a woman who had travelled to the US a month earlier (Shibambu \& Egunjobi, 2020). With cases gradually on the rise, Eswatini experienced its first death in May.

Like a number of its neighbors, South Africa had its first Coronavirus cases in March 2020, with the first confirmed case being that of a returnee from Italy (Shibambu et al, 2020). Soon, SA had the highest number of Coronavirus infections in Africa, especially in Johannesburg and Pretoria, with President Ramaphosa's administration taking a drastic action towards locking down the country. It came as no surprise that by end of March 2020, SA had witnessed the demise of more than 500 people, due to the pandemic (Shibambu et al, 2020). Apparently, Africa experienced corrupt activities by some top officials during the Coronavirus. In SA, for instance, it was estimated that 67 percent of the government COVID-19 funds were corruptly misused by officials (Davies, 2020) at a time unemployment was said to have increased to 30.8 percent (Winning, 2020).

Since the impact narrative of the Coronavirus is ongoing, the pandemic's effect on communities is capricious. Albeit, statistics remain projections as Gondwe's (2020) estimates said that the pandemic would shrink Africa's Gross Domestic Products per capita in 2020 by between 1.4 percent and 7.8 percent, as a result of export adjustments and loss of tax revenue. The author also suggested that the continent's response to the virus was key, hence the suggestion for the implementation of the African Continental Free Trade Area, which would push for the diversification of the continent's economies, as a shield to volatile global commodity prices. It is in the context of projected losses that the International Air Transport Association and the United Nations Economic Commission for Africa estimated revenue losses of approximately US\$113 billion, and US\$65 billion respectively. Even though Africa was one of the last continents to be hit by the Coronavirus pandemic compared to its trade partners, such as the United States of America, China and Europe who were affected by the pandemic earlier, the continent was not exempted from the wrath of the scourge. Besides, economic recession on the continent was projected to also get worse in post-COVID-19 (Gondwe, 2020).

During the Coronavirus pandemic, the 'us' and 'them' also showed itself, especially at the commencement of the pandemic. Some people believed that the scourge was for the Western countries and not for Africa; one of the Zimbabwe Ministers posited that the pandemic was a punishment on America for imposing 'illegal sanctions' on the African states (Matenga, 2020).

Whether or not this was a jocular political statement at a political gathering, this still paints the existing varied perspectives of the pandemic. Despite the likelihood of distorted infection numbers, due to unreliable tracing for Coronavirus cases, Zimbabwe had 8,561 officially infected persons, 8,023 recoveries, and 254 deaths by late November 2020 (Zim SitRep, 09/11/2020). In addition, the handling of the pandemic was marred by corrupt activities that involved the Ministry of Health; the illicit activities included the awarding of a contract of $\$ 60$ million to a company that supplied COVID-19 medical supplies, which in turn, sold the supplies to the government for inflated prices (Chingono, 2020). The real impact of the pandemic remains unknown, and a subject of speculation in Zimbabwe, especially for the number of employees who lost their jobs and the health personnel who got infected on the line of duty. At the commencement of the Coronavirus, the Zimbabwe government faced strikes and demonstrations of civil servants, such as teachers, who sought better salaries. Also, the struggling economy had not done enough to cushion the suffocating businesses, individuals nor families.

\section{Positive Effects out of the Coronavirus}

In addition to the discovery that certain cities were independent of smog during the lockdowns, for instance, India and China, some of the noticeable positives included fewer car crashes and reduced crime rates. Nelson (2020) estimated that approximately 4,000 children under the age of 5 and 73,000 adults above the age of 70 years, might have been saved from reduced air pollution in China (Burke, 2020), while pollution in other cities was reduced by about 20 to 30 percent (NASA, 2020). Nelson adds that, while the pandemic might have caused other negative behaviors, including lack of exercises and poor diets, positives, such as the washing of hands will leave an indelible mark in people's hearts, especially in response to the spread of germs. Empty roads might have induced speeding. Growing evidence also showed that change in societal sexual behavior witnessed reduced numbers of new HIV, syphilis and gonorrhoea diagnoses, as more people heeded the call by health officials towards avoidance of casual 
sex with new partners due to the Coronavirus (Nelson, 2020).

\section{Research Methodology}

This section presents the methodology under which the study was conducted.

\section{Research Design}

This study employed the interpretive phenomenological approach (IPA) to establish the financial, spiritual and social impact of the Coronavirus amongst the members of the four SDA church districts in Masvingo, Zimbabwe. The interpretive phenomenological analysis is 'participant oriented' and it allows the research participants to tell experiences that have been part of their life in the short or long term (Alase, 2017). Through the IPA approach, the respondents told and expressed their lived experiences during the Coronavirus lockdown in Masvingo.

\section{Population and sampling}

The four SDA districts in Masvingo have approximately 4,000 church members who were randomly approached for data collection via the existing WhatsApp groups, since this was during the lockdown. While 35 respondents sent back the questionnaire via the pastors and directly to the researchers, 20 participants would have sufficed to have a frank and open exchange of ideas and information, since qualitative research focusses on meaning and not necessarily with making generalized hypothesis statements (Crouch \& McKenzie, 2006). Ritchie, Lewis and Elam (2003) add that, frequencies rarely matter, since one occurrence of a code or data is all that is necessary in qualitative research, hence small numbers of, say, 20 , still matter. Of the 35 respondents who returned the questionnaires, 20 were males and 15 were females. Of these, 16 were aged between 16 years and 40 years, 10 between 41 years and 45 years, 1 between 45 year 50 years, 6 between 51 and 55 years and 2 were above 55 years. Furthermore, 24 were married, 9 were single and 2 were single parents.

\section{Data analysis and Results}

Data was coded according themes on how the lockdown affected the SDA members financially, spiritually and socially based on the respondents' employment status. The analysis and presentation of results was guided by three specific research questions.
Research question 1: How were the SDA members in Masvingo affected financially during the Coronavirus lockdown?

Data shows that the respondents were financially affected by the lockdown. Their responses varied between being severely and extremely affected by the lockdown. The responses of the formal employees showed that they continued to depend on their salaries, though such salaries soon proved insufficient, as highlighted by one respondent,

Our salaries were already low. Due to the hyperinflation, a salary on its own was never going to be enough. In my family's case, we used salary to begin with, but in a few weeks, it had been expended; we ended up utilizing the savings that we had and the extended period of the lockdown didn't help much.

While ninety-five percent of the formally employed highlighted that they were going to work periodically, one asserted that there was not much of a difference between being home and being at work, given that the organizations were on the brink. The respondent claimed,

There was not much to do at work, but the worst was that my organization struggled to stay afloat and the whole lockdown period was a torcher; by end of the day, there was not much of a difference between being home with my family, and being at work, since the company ended up struggling to pay us.

All the respondents posited that their position was not helped by the closure of the national borders and being dissuaded from traveling between the provinces. Given that the country has been greatly dependent on imports over the past years, the implications of the closed national borders might have affected the respondents differently. While such closure might have affected both the formal and the informal sectors, the latter might have suffered the severest brunt of the lockdown, with one respondent saying,

My business calls for me to travel to surrounding countries, so when the lockdown was effected, I felt the pinch. Our business is largely hand-to-mouth, so the position taken by the state was a blow. I have never seen a revolution at the family level, but I came very close to 
one, as a result of the lockdown; it's that moment when you look like a fool as a man, and I faced my revolution at home.

The financial effects due to the closure of national borders are also synonymous with the experiences noted in Tanzania and other East African states, where cross-border trade contributes between 60 and 70 percent to the national economy (UNDP, 2020). While four of the respondents revealed that they were formally and informally employed, it appears all workers were financially crippled during the lockdown.

The student respondents also revealed their ordeal at home. The lockdown might have led to a lot of socio-economic pressures at home, which did not spare them. One of them observed that,

The reality was that we were at home, even though we had some online classes. During the lockdown, you will discover that we were not allowed even to go outside of the immediate gate, so it was a big challenge for the young people, including me. By the way, when always at home, you eat more, but during the time, my parents could not easily cope with the pressure.

While there could have been individuals and families that might have been helped by a rescue package from the government, it appears there are some who did not, as one respondent said, "I filled in some forms for the government funds, but never received the money."

Another respondent who got some funds from the state claimed that "I got some money from the government package, but it was too little to neither sustain us nor make any significant change to our lives."

While resources dwindled during the lockdown, there were some notable positives on the part of service delivery, and this was captured by a respondent, who claimed that,

Kushata kwezvimwe, kunaka
kwezvimwe (when other things get bad,
others improve). The Coronavirus
helped us though, since we started to
get electricity all the time; we used to
lose it daily between 0530hrs and
2000hrs before the lockdown, while we

would get water approximately once a week; suddenly, we got water daily.

It is apparent that all households were financially affected by the lockdown: those in the formal sector and informal sector, as well as the students, all felt the financial challenges that came along with the lockdown. The government's efforts to help the households with financial rescue packages, which were received by some families, did little to remedy the dire situation. However, it was discovered that one area that might have been addressed by the responsible authorities during the lockdown was the water and electricity situation. The respondents highlighted that during the lockdown, the service delivery of the two commodities improved. Therefore, the lockdown had both negative and positive effects.

Research question 2: How did the lockdown affect the SDA members spiritually?

Given that individuals and families were not permitted to meet during the lockdown, and later were allowed to meet in limited numbers of between 50 and 100 persons, social and religious gatherings were not spared. As a result, some people resorted to meeting in homes during the Sabbath meeting hours, as well as on Wednesdays for the mid-week prayers. It seems a lot of people had to improvise, without creating disharmony with the lockdown and curfew hours. Therefore, several social media platforms were founded at different levels to provide prayer, music and preaching services.

Some of these might have benefitted certain people, especially those that afforded to pay for Wi$\mathrm{Fi}$, while for others, the time proved a spiritual torment. Results showed that respondents were affected spiritually in one way or the other, especially in the first days, with one of them highlighting that,

It was a cultural shock to miss going to church; the first days were desperate and hard for me and my family since we would run short of what to do the whole Sabbath day. The morning was alright, but the after-lunch time started to gradually become boring. I remember some youths who started to watch movie in the afternoons. Moreso, the alternative online church programs were unknown to us. 
Even though alternative media filled in the missing gaps during the lockdown, a statement by one of the respondents could be a reflection of some of the spiritual challenges faced by the SDA Christian community: "some people lost their zeal and energy and they started to miss radio, TV and online programs; they started to do chores they would usually avoid on a holy day." It seems that monotony and boredom became a challenge for some family members, hence the drift from the alternative programs introduced by the church. Another respondent noted that "We were affected spiritually, morally and socially by being isolated from others in the community, church, and even at the family level." Such statements could have also been referring to some of the behavioural changes that might have been observed within and without the immediate families.

It might not have been all gloom though, since there were respondents who postulated how they would go about their church business on the subsequent Sabbaths after the lockdown. It is in this context that a respondent asserted that "I had an individual experience with God. I got to understand him better at a personal level." Another respondent who seems to have spiritually benefitted during the time of the lockdown added, "The pandemic has taught me a couple of things in my life: (1) God has brought me closer to my loved ones (2) He has made me to selfintrospect (3) He has taught me that $\mathrm{He}$ is in control regardless of men's efforts."

As members met as single or more than one family during the week and on the Sabbath, people were affected differently, both positively and negatively as far as spirituality is concerned. The negative impact, for instance, was expressed by a youthful respondent, who explained that,

When we started, it was alright, but boredom crept; it's not easy to see the same faces and speakers each time you meet. By the second week, I started missing the meeting services, given that all the services were done by a single family with a limited number. I missed the youth programs that are usually adventurous, as well as the human touch provided by our church.

To overcome the shortcomings, an alternative to family gatherings was in the form of media of one sort or the other. This was revealed by the fact that sixty percent of the respondents said they accessed the SDA radio programs, including the one provided for the community as revealed by one of the respondents: "We went for a week without knowing that there were programs already which provided services on the Sabbath. The radio alternative was good, especially our Masvingo's Hevoi FM station; the messages that we got around 1100hrs were spiritually enriching."

While the radio might have been the cheapest alternative for the majority of the people, only twenty percent of the respondents hinted that they benefitted from the alternative online programs that they got via the internet, especially those that they got via Facebook and YouTube. Through such platforms, some church-run programs became very popular, especially the "Team Zunde" preaching series, which was broadcasted every Sabbath via the Facebook page under the Mandara SDA church. Another respondent went on to posit that,

To start with, it was awkward to be on Facebook on the Sabbath, which almost caused tension in our place, but after a friend told me about the programs that we could access, we benefitted a lot. The 'Team Zunde program offered by the Mandara SDA church made all the difference. There were a variety of new programs that were offered, from Sabbath school, divine service, to afternoon programs; I also benefitted from the family life programs which recorded programs that could be watched during other times.

While the Coronavirus caused some negative effects, the radio and television programs introduced by the church benefitted members and the church at large. This was revealed by one of the preachers who reported that "...we had a non-SDA, who requested for baptism after benefitting from listening to Hevoi FM..." This was due to the fact that the media reached areas that could not be reached through direct preaching especially during the lockdown. Another positive effect was expressed by a member, who said,

I am a music person, so when I discovered that the church introduced a variety of music and put in place different singing groups, I was thrilled; I can listen to music all day long, and YouTube has provided some of my most appreciated music and groups such as that provided by Gaither Music. 
The utilization of the media amongst the SDA members in Masvingo is consistent with the findings of Shibambu et al (2020) in Southern Africa where church members had similar experiences.

Another effects can be seen from the tithes and offering trends. While the lockdown provided all the efficacious alternatives, which might benefit spiritually, results showed that the church members would have preferred meeting at church; hence they felt affected negatively by the new set-up. For some time and before the Coronavirus pandemic and lockdown, church members had been provided with alternative ways to pay their tithes and offerings, including the likes of Ecocash, use of bank cards and other online banking methods. The researchers further observed that eighty percent of the respondents still afforded to pay their tithe and offerings, despite the lockdown. The other twenty percent might be those that would wish to use the traditional methods of payments that include via the baskets at church or those who were financially crippled such that they could not afford to spare funds for the church. Therefore, the lockdown might have negatively affected the church revenues in that, some members did not afford to submit their tithes and offerings.

Research question 3: How did the lockdown impact the SDA church members socially?

The social effect can be seen from what one of the respondents referred to the lockdown period as "A time of storm and stress." The situation was exacerbated by the fact that people did not visit each other in neighborhoods, let alone across the provinces and borders. That meant relatives could not attend critical functions, including funerals, burials and weddings. One respondent painted a picture of what was experienced then by saying,

The early days were confusing and bad. I lost an aunt and was told by the police at the bus stop on my way to her burial that I could not travel without a police clearance; a picture copy of the burial order could not help me at that moment.

As bad were the restrictions for business, they were equally bad for relationships, especially for family members staying in different countries. One respondent shared an experience from the period by claiming,

My children are here with me in

Zimbabwe for education's sake, but my wife is based in another country. I could not see her from the period of March 2020, till I had to cross the border illicitly in September of the same year. The challenge was that, the border lockdown was longer than the local one, so I was tempted to make a personal decision of crossing the border illegally using a truck driver.

Apart from the negative effects, the lockdown had brought some advantages in a social perspective. While there has been an assertion that genderbased violence might have gone up in and out of Zimbabwe during the lockdown, majority of respondents said the time helped them foster better relationships with their partners and children, as one revealed that,

It was back to the basics; I also
noted that this was a time to be
creative and to bond with my
family; this was impossible before
the lockdown, given our busy
schedules at work and the kids
being in school. We were forced
into an enriching, but financially
cheaper holiday by the virus.

In the same context, one respondent mentioned that they went on their "second honeymoon." Another one said, "Family life came into life during the lockdown." This might be due to a vibrant family life program that is run online by the church. The program facilitates pragmatic presentations from different speakers and presenters; they also engage families while focusing on several themes such as financial literacy, sex, conflict resolution, management, communication, religion, culture and so forth. The lockdown period might have compelled many SDA families into the implementation of some of these themes.

\section{Conclusion and Recommendations}

Based on the findings, the following are conclusions and recommendations of the study.

\section{Conclusions}

The study concludes that COVID-19 lockdown affected all members including students, parents, employed, unemployed, among others. The financial, spiritual and social effects were negative and positive as follows: 
Financially, those in the informal sector suffered the most, compared to those in the formal sector. Employees from key organizations that remained open for business were better financially compared to those that were forced to close. Some desperate families ended up expending their financial reserves. Those businesses that depended on the national borders were greatly affected during the period. The deliberated financial package given out by the government was not accessed by everyone who fell within the targeted groups. The same financial pressures were also felt amongst the locked down students.

Spiritually, the lockdown experience caused both positive and negative effects. Isolation from the church family led to boredom, hence some members watched, and listened non-Christian programs, which affected them spiritually and morally. Some of the members ended up breaking the Sabbath by participating in chores that did not edify spiritually. However, some members benefitted spiritually from the small groups that met. Others found time to introspect, and cultivate better individual and family relationships with The Lord. The radio and television programmes complimented the spiritual growth in others. Those who preferred the traditional methods of returning tithing and paying their offering felt affected by the lockdown, which affected the church, financially.

Socially, members ended up being bored by being indoors. They were unable to visit neighbours, friends and relatives for funerals, weddings and other social functions. The situation was worse for those with relatives across national borders which were closed during the time. However, some members benefited from having more time with their children. Some couples also showed that they had benefited from the period through family reunions. Online programs, such as family life, were critical for the members, since they continued to be shared during the lockdown.

\section{Recommendations}

Based on the conclusions, the researchers recommend that there is a need for a more pragmatic planning towards potential pandemic lockdowns, especially on the part of the government, industry and church. Such planning could include putting in place financial and material rescue packages in place for the households. In addition, effective distributive methods of the rescue packages need to be put in place. It is also recommended that the church should introduce more radio and television programs which will meet the spiritual needs of the members during the lockdown periods in the future.

\section{Reference}

Ackerman, S. (2020, September 13). "US Military Pauses Training Missions in Iraq for Coronavirus," Daily Beast. Retrieved from https://www.thedailybeast.com/us-milit arypauses-training-missions-in-iraq-forcoronavirus

Alam, J., and Kurtenbach, E. (2020, October 10). Fashion labels cancel order during coronavirus, garment workers go unpaid. Retrieved from https://fortune.co $\mathrm{m} / 2$ 020/03/27/coronavirus-fashion-industry workers/

Alase, A. (2017). The interpretative phenomenological analysis (IPA): a guide to a good qualitative research approach. International Journal of Education \& Literacy Studies, 5(2), 9-19.

Arezki, R., and Nguyen, H. (2020). "Novel coronavirus hurts the Middle East and North Africa through many channels." In Baldwin and di Mauro (Eds.), Economics in the time of COVID-19. London. CEPR Press.

AU and UNDP. (2020, July 27). The impact of the COVID-19 outbreak on governance, peace and security in the horn of Africa.

Basit, A. (2020). The COVID-19 pandemic. Counter Terrorist Trends and Analyses, 12(3), 7-12.

Bartik, A. W., Bertrand, M., Cullen, Z., Glaeserd, E. L., Lucac, M., and Stanton C. (2020). The impact of COVID-19 on small business outcomes and expectations. PNAS, 117(30), 17656-17666. doi:10.1073/pnas. 2006991 117.

Boniol, M., Mclsaac, M., Xu, L., Wuliji, T., Diallo, K., and Campbell, J. (2020, September 14). Gender equity in the health workforce: Analysis of 104 countries. Retrieved from https://apps.who.int/iris/bitstream/handle/ 10665/311314/WHO-HIS-HWF-GenderWP1- 2019.1- eng.pdf

Burke, M. (2020, October 10). Covid-19 reduces economic activity, which reduces pollution, which saves lives. G-FEED.org. Retrieved 
from www.g-feed.com/2020/03/covid-19reduces-economic-activity.html

Chingono, N. (2020, July 09). Zimbabwe health minister facing coronavirus corruption charge sacked. The Guardian. Retrieved from https://www.theguardian.com.

Crouch, M., and McKenzie, H. (2006). The logic of small samples in interview-based qualitative research. Social Science Information, 45(4), 18. doi: 10.1177/0539018406069584.

Davies, P. (2020, September 03). South Africans protest as report reveals COVID-relief fund misuse. Africanews. Retrieved from https://www.africanews.com.

Dube, M. (2020, September 14). Botswana, with No COVID-19 Cases, closes borders after death in Zimbabwe. Retrieved from https://www.voanews.com/sciencehealth/c oronavirus-outbreak/botswana-no-covid19-cases-closes-borders-after-deathzim babwe.

Kahla, C. (2020, September 14). Report: COVID-19 pandemic could likely last for another two years. Retrieved from https://www .thesouthafrican.com/technology/science/c ovid-19-pandemic-likely-last-twoyearsreport-m a y-2020/.

Gannon, K. (2020, October 15). "Taliban ready to begin cease-fires in virus-hit Afghan areas," Washington Post. Retrieved from https://www.washingtonpost.com/world/as ia_pacific/taliban-ready-to-begin-ceasefires-in-virus-hit-afghanareas/2020/04/ 01/ bcdd5f5e-7438-11ea-ad9b254ec99993bc_ stor y.html.

Gondwe, G. (2020, July). Assessing the impact of COVID-19 on Africa's economic development. UNCTAD/ALDC/MISC/2020/3.

Gostin, L. O. (2014). Global Polio eradication: espionage, disinformation, and the politics of vaccination. The Milbank Quarterly, 92(3), 413-417.

Gostin, L. O. (2020). "Globalized health hazards the need for collective global action," in Global Health Law. Harvard University Press.

Haldevang, D. M. (2020, September 13). Coronavirus is imperiling billions of informal workersespecially women. Retrieved from https://qz.com/1831326/coronavirus-impe rils- billions-of-informal-workers-especiallywomen/.

Iroulo, L. C., and Boateng, O. (2020). African states must localise Coronavirus response.

German Institute of Global and Area Studies, 3, 1-13.

Joscelyn, T. (2020, September 13). "How Jihadists Are Reacting to the Coronavirus Pandemic," Foundation for Defence of Democracies. Retrieved from https://www.fdd.org/anal ysis/20 20/04/06/howjihadists-are-reactingto-the-coronaviruspandemic.

Magnay, D. (2020, November 15). COVID-19: Russia's approach to vaccine 'rat race' has echoes of its spirit in the Cold War. Sky News. Retrieved from https://news .sky. com.

Malik, S., and Naeem, K. (2020). Impact of COVID-19 pandemic on women: health, livelihoods and domestic violence. Sustainable Development Policy Institute, Policy review.

Matenga, M. (2020, March 16). Muchinguri touches raw nerve. Newsday. Retrieved from https://www.newsday.co.zw.

NASA. (2020, October 10). Airborne nitrogen dioxide plummets over China. Retrieved from www.earthobservatory.nasa.gov/images/14 6362/airborne-nitrogen-dioxide-plummetsover-china.

Nelson, B. (2020). The positive effects of COVID-19, BMJ. doi: 10.1136/bmj.m1785.

Nicholls, D. (2020, September 13). "Army redeploys troops home from Iraq as Coronavirus forces end to training mission," The Telegraph. Retrieved from https://www.telegraph.c o.uk/news/2 020/03/ 19/armyr edeploys-troops-homeiraq-coronavirus-forces-endtraining/.

Nkwe, M. (2020, June 01). Gender based violence increases in Zimbabwe. Gender links for equality and justice. Retrieved from https://genderlink.org.za.

Oduor, M. (2020, November 27). Madagascar takes last stand on Covid-19 vaccine, refuses immunization. Africanews. Retrieved from https://www.africanews.com. 
Reston, M. (2020, October 25). Trump and Pence ignore COVID-19 risk even as it spreads among inner circle. CNN. Retrieved from https://www.cnn.com.

Ritchie, J., Lewis, J., and Elam, G. (2003). “Designing and selecting samples." In Ritchie, J. and Lewis, J. (Eds.), Qualitative research practice. A guide for social science students and researchers. Thousand Oaks, CA: Sage, 77-108.

Shibambu, N. J. and Egunjobi, J. P. (2020). The impact of COVID-19 pandemic lockdown on the community life of religious men and women in Southern Africa. DOI: 10.13140/RG.2.2.29845.96481.

Wenham, C., Smith, J., and Morgan, R. (2020, October 10). COVID-19: the gendered impact of the outbreak. Retrieved from https://www.thelancet.com/journals/lancet /article/PIIS0140-6736(20)30526-2/fulltext.

UNDP. (2020, April). Rapid socio-economic assessment impact of COVID-19 in Tanzania.

Winning, A. (2020, November 12). South Africa's unemployment rate reaches record high above 30\%. BBC World News. Retrieved from https://www.uk.news.yahoo.com.

World Health Organisation. (2020, November 23). Coronavirus disease (COVID-19) pandemic update. Retrieved from https://www .who.i nt/e me rgencies/diseases/novelcoronavirus-2019?gclid=CjwKCA iA2O39BRB jEiwApB2lkmHFBV40kptmIXsMBQVNFNArO AV1GMzdGdXJF8kc9rEUcLRXCgF9vRoCP4QAvD BwE.

Zim SitRep. (2020, November 09). Zimbabwe COVID19 cumulative cases. Retrieved from https://www.http://www.reliefweb.int. 